\title{
Additional professional education in a region as an indicator of its quality
}

\author{
Marina Aldoshina $^{1 *}$ and Svetlana Artamonova ${ }^{1}$ \\ ${ }^{1}$ Orel State University named after I.S. Turgenev, Department of Technologies of Psychological, \\ Pedagogical and Special Education, Orel, Russia
}

\begin{abstract}
The problem of transformation in the field of education and educational services is actualized by a wide range of concerned parties (specialists, parents, managers, government representatives). The innovative development vector has emerged also in the field of education through numerous upgrades and reforms (implemented and announced) focused on consideration of the specific socio-cultural features, such as sanitary and epidemiological situation, technologization, and digitalization of education, upgrading of the ethnic and cultural identity of regions in the context of growing migration flows and growth of the ethnic factor in the personality's upbringing. The methodological background of the present research is based on the competence approach. The article presents an analysis of scientific research on the issue of pedagogical professional competence as the main resource that provides innovative processes and prospects for the development of additional education; highlights the essential characteristics of the concept of professional competence of a teacher, which are focused on the system of additional education through participation in project activities. The article substantiates the necessity of forming the professional competence of a teacher of additional education in innovative practices of contemporary technological society, modeling a new educational infrastructure capable of creating modern training resources in regional systems of additional education. The innovative experience of implementing the Federal project "Success of every child" of the national project "Education" aimed at creating new vacancies in the system of additional education for children of the Orel Region is considered for the first time. The authors contemplate the practices of additional education that are in demand among parents and students and are provided by the Quantorium Technopark in the city of Orel.
\end{abstract}

Keywords: additional education system, educational projects, children's giftedness.

\section{Introduction}

The development of contemporary education in the Russian Federation, targeted for the period up to 2030, is focused on the formation of a new education system that involves constant updating, ensuring global competitiveness and quality, as well as meeting the

* Corresponding author: maraldo57@,mail.ru 
current and future needs of the individual and society. As a significant and variable part of the entire national educational space, the system of additional education is the most valueforming resource that actively absorbs and flexibly implements all the innovative transformations of the present time $[1,2]$. In today's context, there are quite many criteria indicating the quality of life in the region, of which educational ones are becoming increasingly important. The range of service offers and quality of their implementation in the field of regional additional education indicate the quality of occupancy and quantitative choice (fact criterion), as well as the possibility of meeting educational needs, taking into account the trajectory of personal development and the potential for creative growth of the student (quality criterion).

\section{Methods}

Using the methods of comparative analysis, content analysis, and monographic research, it can be stated that research in the field of additional education is reflected in scientific works [3-6]. Thus, A.G. Asmolov states: "Today, additional education is beginning to change the educational reality. It can't be constrained by a class- and lesson-based system... Additional education turns the creativity of children's and adolescent's subcultures into a key resource for the society development" [7]. Besides, the scientist notes that "Additional education is a key mechanism of adaptation to changes, especially necessary nowadays, when, as they say, "the very changes change"" [7].

The increased interest in the development of modern additional education actualizes the need for a prospective update of this system [8-12] as a special model of functioning in the field of providing educational services due to the social order of society, and for providing it with the main criterion for the quality of the professional and pedagogical activity, i.e. a competent personal resource.

Within the framework of the State Program of Education Development for 2019-2025 [13], several relevant projects have been devised aimed at "implementing measures to form contemporary managerial, organizational, and economic mechanisms in the system of additional education for children" [13], developing the national system of professional growth of highly qualified teaching staff, as well as supporting "the implementation and dissemination of innovations in the education development and modernization" [13].

In the context of these priority areas of state transformations, pedagogical professional competence is considered as an important resource and the main guarantor providing modernization innovation processes and development prospects in additional education.

Analysis of scientific and pedagogical literature suggests that the majority of researchers $[3,4,6,14]$ represent pedagogical competence as a complicated complex phenomenon that combines professional knowledge, experience, attitudes, and qualities of a person motivated by the desire for continuous education, self-improvement, and selfactualization, which allows them to effectively perform their activities. Indeed, only being in the mode of self-actualization and self-development, today's teacher is able to build own trajectory of professional activity that would meet new innovative and promising areas in the additional educational space, dictated by the needs of society and the state.

Today, the entire contemporary system of additional education, as well as society in general, are focused primarily on the needs for a completely different competence component of a specialist, which would allow correlating and using fundamental basic knowledge, practical experience, and innovation, mobility and adaptability in a new format of designing, modeling and implementing priority intellectual and educational resources. 


\section{Results}

The format of the prospective development of professional competence in additional education involves updating the content and technologies in this area, implementing project-based methods of activity, implementing practice-oriented modules of qualification growth, exclusive software and methodological support, as well as forming modern organizational and economic conditions and management mechanisms. The complex of these procedures models a qualitatively new, special educational infrastructure capable of creating an innovative environment for obtaining educational resources in regional systems of additional education. One of these modern educational infrastructures today is a standard model for creating new places in children's additional technical education.

The regional development model of the technical education system provides for further multilevel development and improvement of technological literacy and advanced skills of students in technical and natural sciences, the creation of groups of young makers, the formation of pre-service orientation and creative activity through implementation of modern technologies, forms and means of education under equal and affordable conditions of mastering the latest quality software. The created innovative resources help to identify and support young talents, children's giftedness, individual personal development trajectory, as well as update the content of additional education in general.

The defining structure of these transformations is undoubtedly the integrity and identity of the personnel-competence, organizational, and substantive components in the integration interaction with various profiles and branches of additional, general, and professional education, combined with the socio-economic conditions and demographic characteristics of a particular region.

Thus, in 2019, the Orel Region joined the implementation of the Federal Project "Success of every child" of the National Program on Education, whose main goal was to implement into the educational sphere of the region a set of measures aimed at expanding and developing the scientific and creative potential, as well as the system of highly qualified personnel of additional education. First of all, this concerned the formation of a dynamic integrated educational platform that ensured the availability and quality of additional education services in combination with modern models of functioning and software, as well as implemented innovative training technologies and methods in combination with the professional competence component of the teacher as the main resource for optimization and innovation.

In this regard, advanced training courses organized and conducted by the Orel Institute of Education Development were quite expedient and timely. These courses were dedicated to the issues of psychological and pedagogical support for gifted children and the implementation of technical programs based on robotics and industrial design.

This qualification program training actualized the successful implementation and testing of modern digital technologies and software in professional-pedagogical practice, as well as methods of psychological and pedagogical identification and development of children's abilities for research, intellectual, scientific, and creative activities within the framework of regional project activities.

One of such significant and large-scale transformations in the region is the creation of the children's Quantorium Technopark as a resource center for additional technical education. This is an innovative educational platform equipped with modern high-tech facilities, software, and system support, with competent teaching staff, involving highlyqualified specialists, engineers, scientists, and postgraduates, who have passed multistage qualification selection and competitive regional tests.

Based on the implementation of additional general educational modular programs of technical orientation, students receive and master a broad range of knowledge and skills in 
scientific and technical creativity, research activities, acquire teamwork skills using case technologies, information and communication competencies, creativity, and critical thinking. Six innovative technical areas, namely, IT-quantum, Promroboquantum, Autoquantum, Aeroquantum, High-tech Shop, and Bioquantum are successfully functioning within the framework of the Orel children's Technopark.

The next example of implementing innovative educational practices in the region was the commissioning of the center named Eagle Constellation aimed at identifying, supporting, and developing the abilities and talents of children and youth. This Center provides additional educational services in the scientific field, as well as in the field of art and sports. The educational activities of the Center include full-time form and part-time form of training using remote technologies, a changeover-based children's stay, and includes modular programs of additional education and upbringing.

This open multistage, modular educational and pedagogical innovative practice in the region, accompanied by the inclusion of a monitoring system to optimize the learning process, will not only train young engineers and makers but also track and identify talented students to transfer them to more in-depth training. Perhaps such gifted children will be able to take part in real scientific and creative projects that have a promising significance not only within a particular region but also throughout the country.

\section{Discussion}

It is obvious that additional education is one of the significant and variable parts (spheres) in the general system of contemporary education, which has a huge pedagogical, social, cultural, and creative potential. The development of this unique type of educational practice in the region is a fertile ground for testing and modeling a new educational infrastructure capable of creating and developing high-quality training resources at the present stage.

The key link and effective mechanism for the functioning of the studied transformations are undoubtedly the competence-based workforce capacity, which is able not only to adapt to the changing conditions of educational reality but also to implement promising projects and ideas of social, societal, and scientific significance.

\section{Conclusion}

Thus, the innovative practices and trends of additional education in the Orel Region considered in the present study, are focused on creating optimal pedagogical conditions for a universally accessible environment contributing to uncovering and developing the creative potential, abilities, and talents of children. It is no accident that when addressing the Federal Assembly, President V. Putin noted: "Our entire education system should be based on a fundamental principle: every child is gifted, and it is our task to reveal their abilities. This is Russia's success" [14]. This means that it is necessary to form a new system of national education that would provide for a qualitative update and development of its content at the regional level by expanding the range of information technology-based educational services and providing a competent pedagogical personal resource.

\section{References}

1. The concept of the development of additional education for children. Order of the Government of the Russian Federation dated September 4, 2014 No. 1726-r. Accessed on: December 20, 2020. [Online]. Available: 
http://static.government.ru/media/files/313b7NaNS3VbcW7qWYslEDbPCuKi61C6.pd $\mathrm{f}$

2. K. Shore, Special Kids Problem Solver: Ready-to-Use Interventions for Helping All Students with Academic, Behavioral, and Physical Problems (Jossey-Boss, San Fracisco, 2019)

3. M.I. Aldoshina, Psychological and pedagogical search, 1(41), 90-96 (2017)

4. M.V. Boguslavsky, I.D. Lelchitsky, E.V. Neborsky, Modern system of russian higher education in the context of stratification, 7th icCSBs 2018 The Annual International Conference on Cognitive - Social, and Behavioural Sciences. Conference proceedings, 100-108 (2019)

5. S.V. Ivanova, V.V. Serikov, Pedagogy, 2, 3-12 (2017)

6. O.B. Ivanov, S.V. Ivanova, Philosophy of Science, 1, 39-49 (2016)

7. A.G. Asmolov, Educational policy, 2, 36-40 (2014)

8. L.P. Illarionova, Social pedagogy, 5, 91-93 (2013)

9. V.V. Serikov, Bulletin of the Kalmyk University, 2, 72-78 (2012)

10. J.L. Hart, Interpreting cultures: Literature, religion and the human sciences (Basingstoke Hants, New York, 2006)

11. M.I. Aldoshina, A.G. Knyazeva, V.A. Nikolaev, EpSBS 69-EEIA (2019). https://doi.org/10.31992/2018.116

12. T.A. Minke, Types of Homework and Their Effects on Students. Culminating Projects in Teacher Development, (St. Cloud State University, Stanford, 2017)

13. State Program of the Russian Federation "Development of Education" (as amended on August 14, 2019). Resolution of the Government of the Russian Federation of December 26, 2017 No. 1642 (2019). Accessed on: December 20, 2020. [Online]. Available:

http://static.government.ru/media/files/313b7NaNS3VbcW7qWYslEDbPCuKi61C6.pd $\mathrm{f}$

14. Message from the President of the Russian Federation V.V. Putin to the Federal Assembly 12/01/2016, Accessed on: December 20, 2020. [Online]. Available: http://static.government.ru/media/files/313b7NaNS3VbcW7qWYslEDbPCuKi61C6.pd f 